\title{
Construction and Application on Teaching Resource of Basic Computer Course
}

\author{
Jinshan Liu ${ }^{1, a^{*}}$, Wenbo Yuan ${ }^{2, b}$ and Xiaojing Yang ${ }^{1, c}$ \\ ${ }^{1}$ Xi'an Shiyou University, school of computer science, Xi'an Shaanxi 710065, China \\ ${ }^{2}$ Inner Mongolia Electronic Information Vocational Technical College, Department of Electronic \\ Engineering, Inner Mongolia, Hohhot, 010070, China \\ a54048942@qq.com, b317536504@qq.com, c123950648 @qq.com
}

*The Corresponding author

Keywords: Computer basic course; Teaching resource; Self-access

\begin{abstract}
Basic computer teaching is facing the reform of teaching content, teaching time cannot meet the needs of class, so need to increase the extracurricular teaching time. In order to ensure that students can improve their ability in extracurricular self-study, we need to establish computer-based teaching resources. This paper discusses the principles of computer basic teaching resources construction, analyzes the problems of teaching resources, and puts forward the construction of computer teaching resources.
\end{abstract}

\section{Introduction}

The Ministry of Education College of computer science and Technology Teaching Guidance Committee in the "Opinions on further strengthening computer basic teaching of higher college" that would "strengthen practice teaching, pay attention to the training of ability", and pointed out that the students should have computer knowledge structure, namely "to understand and master the computer hardware structure and composition principle, to understand the operating system functions and some important concepts, understand the program design, computer network, database, multimedia technology fields of application, the basic concept and the related technology, master the basic application of computer skills." In order to meet the requirement, it is necessary that strengthen teachers' guide, strengthen students' self-training and the cultivation of practice ability, calling all technical means to cultivate students' innovation consciousness in the teaching of computer basic courses. In the actual teaching, only depending on the classroom teaching is not enough, should make full use of the students' spare time, mobilize the enthusiasm of students, to play the role of campus network, for students' spare time to learning to create the necessary conditions, we construct the teaching resources based on campus network.

\section{Principle of Construction on the Computer Basic Teaching Resources}

The construction of computer basic teaching resources is not the simple accumulation of teaching materials and information. The construction of computer basic teaching resources based on network should follow the law of education and teaching, in order to achieve the Internet sharing, facilitate the teachers and students to use as a target, should adhere to the reliability, flexibility, openness, security principle, unified planning, unified standards, unified management.

Reliability. It is very important that computer basic teaching resources of the reliability of the system. Due to the large number of computer basic teaching resources, the system must use the superior performance of the server, is conductive to reducing a large amount of data throughput time, so that the whole system of management standardization. And with the increase of consumers and the expansion of the operation time, does not affect the normal operation of the system. In addition, the catastrophic failure occurred after in a short period of time to restore, the data integrity, security protection. In addition, data can be restored in a short period of time after the catastrophic failure occurred. At the same time data can be guaranteed of integrity and security. 
Flexibility. The management of computer basic teaching resources should have larger flexibility and expansibility in data management. It can be centralized management of all resources, or can be divided according to the type of resource, individual management. The system should also provide various types of interface, can be incorporated into all kinds of teaching resources management system.

Openness. Network teaching involves professional range, and number of participants, the teaching contents of complex. So it is requirements that the system with complete openness and it can able to accommodate various forms of online teaching content. The system should support the open file format, can manage all capable of running on Internet course content and format.

Security. The computer basic teaching resources are based on the network and opened, so the safety is a prerequisite for providing service of the network teaching information resources. It is including that the safe use of hardware, remote access and the security of local area network information transmission, the security that different permissions for user access to various levels of information and so on.

\section{Types of Teaching Resources and the Existing Situation}

Network teaching resource is the prerequisite and foundation that students studying in his spare time. With the popularity of campus network, the network teaching resources become more and more abundant, and the effective management of teaching resources becomes the key. It provide efficient storage management for all type of learning content objects, it provide convenient access function for users, it provide resources evaluation for teaching management, so as to improve the teaching resources utilization, promote the teaching resources to better practical teaching system.

Network teaching system of information resources includes media material, courseware, VOD video, a testing system and software teaching resources library, etc. We can see the table below.

We conducted a survey on the information resources network teaching system of 50 colleges and universities in Xi'an, and the specific situation, Including media materials, courseware, video on demand, test systems and software teaching resources. We can see the following table 1.

Table 1 Information Resource Survey

\begin{tabular}{|c|c|c|}
\hline Types of Teaching Resources & Ownership situation [\%] & Use situation [\%] \\
\hline Media Material & 98 & 64 \\
\hline Multimedia Courseware & 80 & 56 \\
\hline VOD Video & 84 & 68 \\
\hline Test System & 42 & 12 \\
\hline Learning Software & 100 & 66 \\
\hline
\end{tabular}

Media Material. Media material is the basic material unit of spread teaching information. It can be divided into five categories: text material, graphics material, and audio material, video material, animation material. According to the categories, teachers can easily call for various materials to make multimedia courseware from the multimedia material library, or display a picture, sound, animation, video material for classroom teaching through network. Students can also access, watch, and download all kinds of material for learning through the network.

Multimedia Courseware. Courseware is a targeted teaching resource. According to the running platform division, it can be divided into the single version of the courseware and the network version of the courseware. The single version of the courseware placed in the library after the compressed. Students should download the single version of courseware and then decompression it. Based on the Web network courseware and network curriculum can be directly on the net play. It should has the permissions to different users of courseware upload, download, management, and other functions, so that the entire system of maintenance and management, and teachers on the independent development of the courseware for copyright protection. 
VOD Video. The video and audio resource is relatively complete, longer video material, such as teaching video, teaching case, class film, and patriotic education film. It is converted to a digital media stream format through the video compression technology, stored in the video server. Teachers and students can be in online real-time VOD, and retrieval, and choose to watch according to their own competence level of video data.

Test System. The test system can be completed on the students' learning situation detection. It was placed in various disciplines, typical, reflect the different levels of support, judgment, choice, matching, sorting, and fill in the blanks, question answering and other forms of question. Examination questions grade classification of storage according to the department, specialty, and curriculum. Examination questions library is open, administrators or teachers can flexibly add, delete test questions in the examination questions. We can use test system flexible, automatic selection, automatic evaluation, statistics, sorting and so on.

Learning Software. Learning software is targeted to a curriculum development learning system. Students can learn from the shallower to the deeper for a course in the software instruction, step by step way. Learning software includes language, sound, animation, video and other means, student can interactive with it. When the student put forward their own questions, the learning system can give the answers. At the same time, the learning system also can give student the question, if the student answers correctly, he can move on to the next question for study, as the game only through the front gate, in order to enter the next level for new games. This learning system can attract students' interest in studying.

\section{Problems in the Construction of Teaching Resources}

Lack of All Kinds of Teaching Resources. At present, the school site was more or less to provide some teaching resources, including the press also provide teaching resources. But these teaching resources basically are with the character and PPT courseware mainly. These teaching resources only have text and relatively simple animation, only provide a help to give teachers. It does not have a good auxiliary effect to the students' self-learning and review of the literature.

Construction of a Lack of Interactive Teaching Resources. Teaching resources content must have a certain degree of interactivity. (Interactivity includes between the users, content publishers management between the users.) Lack of interactive teaching resource content is the old forms that cannot be changed of teaching and preaching.

The interaction between students and the teaching content is to have content in any situation of education. But now the online course is mainly using video and text mode (web based education), PPT notes (common class), teaching content is shared to the network through the text and simple presentation. Students learn the corresponding course knowledge, complete the relevant operation and take part in the examination through the network. But this approach only has the display function, do not provide interactive function, cannot maximize the advantages of interaction in the network. It does not favor the student to personalized learning, does not take the student as the center. It is difficult to study active learning enthusiasm. In addition, the lack of interactive function of the existing teaching resources, even if the students have a little problem, he had to watch the teaching resources to explain, waste a lot of valuable learning time for students. And only the problem has a solution, not only to provide students with different explanations on the students' understanding of the problems, but also has some drawbacks.

Improving Students' Initiative on Using of the Teaching Resources. Due to the students do not have to use the network learning, students will not take the initiative to open the network teaching resources for learning, how to guide the students to active learning has been to be a subject of educators. On the network, a lot of game software can attract the surfer's attention, even to an obsessive, the key is that the game can stimulate the interest of Internet users, is willing to take the initiative to play game. Development and design of the better teaching resources, to attract the attention of students, although not to the network game so addictive, at least let learners don not feel boring, gradually achieve the students can actively use the network teaching resources for learning purpose. 
The Lack of Teaching Resources Management. The Internet has a wealth of information, and information sharing is the Internet's purpose that determines the Internet disorder. Although the search engine technology provides the convenient to find the information, the current search engine is not able to do it according to the needs of users of quantitative and qualitative to complete the specified content query task. The campus network provides a learning environment for the students' online learning, in order to ensure the students to effectively use of teaching resources, teaching resources must be on the effective organization and management. But many colleges and universities upload all kinds of teaching content altogether to the network server in order to enrich the teaching resources. The lack of resource management concepts, it has some trouble of teachers and students to use, and also affect the effective maintenance of the campus network educational resources. Some of the network teaching resources are uploaded to the network, little maintenance, some webpage link failure, resulting in more students not willing to undertake the network learning.

\section{Construction Based on the Network Teaching Resources}

According to the use of teaching resources, the network teaching resources can be divided into: teaching resources, experimental resources, students' autonomous learning resources, student online examination and appraisal resources and other resources. These resources can be unified construction of network learning platform, students $\log$, is free to use, for review or for self-study students provide effective help.

Construction of Network Teaching Resources. Network teaching resource construction include teaching information, such as: the basic requirement of teaching (Syllabus), teaching schedule (Calendar), assessment of students (Syllabus), electronic teaching plan, teaching with cases and teaching auxiliary AV data. These data are used in the process of teaching material for students' self-study, although also has certain guiding significance, but could not play a key role.

Construction of Experimental Resources. The experimental teaching resources include laboratory, experimental equipment of the function and the use of methods, instruments and equipment common issues described, and the basic requirements of the experiment, the experiment content and objective description of the content. These elements can help students master the main experimental methods and instruments using skills, help students better finish the experiment. We use experimental teaching video to illustrate and explain the process of experimental teacher's record, on a web site, can be in the process of experiment greatly reduced experiment workload, and increase the students to do experiments with confidence.

Students' Self-Access Resources. Students' autonomous learning resources are defined based on the network teaching software, this software system can provide students a course knowledge point, as the teacher himself for a student lectures, offers one to one teaching. The resource is not simple teaching image integration, but is the use of computer software technology design and development of application system. Through a variety of animation techniques, the system image of the presentation of the course difficult. It played a significant role for students to understand the courses.

Students Online Examination Resources. When the student learns the knowledge by using the learn software, he can choose to enter the test. If student can pass a test that is complete study, else the system can point to the knowledge to explain a different angle.

Evaluation of Resources. Evaluation of resources has an automatic score in the examination system. It can not only fill in the blanks with the correct selection, assessment, objective questions, at the same time to assess students' ability to program design, a variety of control assessment as well as a variety of operating the automatic scoring. After using this system, the usual assessment simplistic, and teachers can give tests timely, students answer, immediately draw result. 


\section{Conclusions}

Excellent teaching resource plays a great help to students learning. It is a great significance that we construct a content rich, beautiful interface, function of campus network based on computer foundation teaching resources platform of computer course teaching reform.

\section{References}

[1] Q. Chen: China Modern Education Equipment, Vol. 156(2007) No.10, p.71. (In Chinese).

[2] R.R. Xie: Journal of Distance Education, Vol. 92(2015) No.1, p.87. (In Chinese).

[3] Z.Y.Zhou: Network Learning and Educational Reform (Zhejiang: Zhejiang University press, Chinese 2006). (In Chinese).

[4] L. Wang and X. Sun: Journal of Jiangsu Radio \& Television University, Vol. 132(2008) No.5, p.79. (In Chinese).

[5] Y.Z. Chen and J.Q. Li: Computer Knowledge and Technology, Vol. 10(2014) No.15, p.3607. (In Chinese).

[6] D.G. He, B.W. Sun and D.L. Zhang: Computer Education, Vol. 52(2010) No.20, p.69. (In Chinese).

[7] Information on http://www.icourses.cn.

[8] Q. Chen and X.P. Hu: Modern Educational Technology, Vol. 287(2011) No.12, p.112. (In Chinese).

[9] X. Zheng, T.H. Huang and L. Chen: Journal of Beijing Radio and Television University, Vol. 89 (2011) No.3, p.51. (In Chinese).

[10]F.J. Yu: Electronic Test, Vol. 263 (2016) No.15, p. 86. (In Chinese). 